\title{
AGROGSTA
}

Journal Agroista. Vol. 5 ,No.2 November 2021

Journal home page: https://jurnal.instiperjogja.ac.id/index.php/AGI

ISSN : $2597-3835$

e-ISSN : : $2684-7019$

\section{RESPON PEMBUNGAAN TURNERA SUBULATA TERHADAP INTENSITAS PENYINARAN DAN MACAM PUPUK P}

\section{RESPONSE OF TURNERA SUBULATA FLOWERING ON LIGHT INTENSITY AND TYPE OF PHOSPHOR FERTILIZER}

\author{
Umi Kusumastuti Rusmarini ${ }^{1}$, Lilik Eko Mardiyanto ${ }^{1}$ \\ ${ }^{1}$ Department of Agrotechnology, Faculty of Agriculture, Stiper Agricultural Institute, \\ Yogyakarta, Indonesia \\ E-mail korespondensi: umikusumastuti.rusmarini@gmail.com
}

\begin{abstract}
Turnera subulata is a benefit plant for oil palm, the flower is habitat for enemy of oil palm insect. This study aims to know the response of Turnera subulata flowering on light intensity and different kinds of phosphor fertilizers. The research was conducted in STIPER Agricultural Institute Yogyakarta. The research used split plot design as experimental method with two factors. The first factor is light intensity which is consisted of 3 levels: $54,9 \mathrm{fc} ; 20,4 \mathrm{fc}$; and 9,8 fc. The second factor is the type of phosphor fertilizers: TSP, SP36, Gandasil B, and Control. The results are analysed with Variance and Duncan's Multiple Range Test, $5 \%$ significance. The research showed that there is interaction effect between light intensity and phosphor fertilizer which is resulted in the amount of flower and flower age of Turnera subulata. Application of 54,9 fc light intensity combined with Gandasil B fertilizers give the best response for the amount, age, and also growth of Turnera subulata.
\end{abstract}

Keywords: Turnera subulata, light intensity, Gandasil B, TSP, SP36 


\section{PENDAHULUAN}

Peluang pengembangan kelapa sawit Indonesia di masa depan masih sangat besar terkait dengan harga minyak yang semakin kompetitif dan tingginya permintaan minyak sawit dunia untuk produk pangan maupun non pangan terutama untuk bahan bakar hayati (biofuel). Meskipun lahan yang sesuai dengan karakteristik lahan yang optimum untuk budidaya tanaman kelapa sawit sangat terbatas di Indonesia, hal ini mendorong untuk kelapa wasit ke lahan-lahan marjinal dengan berbagai faktor pembatas (Rahutomo dkk, 2007)

Kelapa sawit merupakan tanaman yang mampu menhasilkan minyak tertinggi dibandingkan jenis tanaman lainnya. Indonesia merupakan negara penghasil minyak terbesar di dunia. Kebutuhan minyak sawit terus meningkat sejalan dengan peningkatan jumlah penduduk dunia. Permintaan kelapa sawit yang terus meningkat juga dipacu oleh berkembangnya teknologi pengolahan seperti industri eleokimia.

Peningkatan produksi kelapa sawit di Indonesia tidak lepas dari beberapa kendala antara lain adanya serangan hama. Hama utama yang menyerang tanaman kelapa sawit dan sangat merugikan adalah ulat pemakan daun kelapa sawit (UPDKS) yaitu ulat api khususnya Setothosea asigna. Ulat ini memakan daun kelapa sawit terutama daun yang dalam keadaan aktif yaitu daun nomer 9 - 25 (Lubis, 2011). Defoliasi yang mencapai hampir 100\% pada TM berdampak langsung terhadap penurunan produksi sampai $70 \%$ dan $93 \%$ bila terjadi serangan ulangan pada tahun yang sama (Pahan, 2008).

Setothosea asigna merupakan hama pemakan daun kelapa sawit yang mempunyai siklus hidup terdiri dari empat stadium yaitu telur, larva, pupa, dan imago. Laju perkembangan ulat api didukung oleh kemampuan berkembang biak dan waktu yang diperlukan untuk menyelesaikan siklus hidupnya. Semakin tinggi daya berbiak dan semakin pendek siklus hidupnya maka semakin cepat laju pertambahan populasinya.

Pengendalian ulat api dapat dilakukan dengan pengendalian secara kimia dengan insektisida tetapi dapat membahayakan serangga lain yang merupakan predator maupun parasitoidnya. Oleh karena itu dibutuhkan cara pengendalian yang aman dan ramah lingkungan. Salah satu cara pengendalian tersebut adalah pengendalian hayati. Pengendalian dengan jamur Paecilomyces fumosoroseus dan Beauveria bassiana dapat membunuh Setothosea asigna yang menyerang daun kelapa sawit sebesar $100 \%$ pada 24 hari setelah aplikasi (Dongoran, dkk.2007). 
Selain pengendalian dengan jamur pathogen, pengendalian secara biologis dapat dilakukan dengan menanam Turnera subulata yang merupakan habitat musuh alami ulat api yaitu Sycanus dichotomus. Serangga ini mencari nektar pada bunga Turnera subulata atau bunga pukul delapan karena bunga ini akan membuka pada pukul delapan dan menutup pada pukul 11.00 atau 12.00 .

Turnera subulata yang dkenal juga dengan bunga pukul delapan merupakan tanaman berguna (benefit plant) dari famili Passifloraceae yang berasal dari Meksiko dan Hindia Barat. Bunga pukul delapan merupakan herba dengan tinggi $60-90 \mathrm{~cm}$ dan memiliki akar dengan panjang $30-80 \mathrm{~cm}$, daun berwarna hijau dengan panjang $2-7 \mathrm{~cm}$ dan lebar $1-4 \mathrm{~cm}$. Bunga pukul delapan hanya mekar beberapa jam saja yaitu dari pukul 08.00 sampai pukul 12.00 . Warna bunganya putih sedangkan spesies lainnya berwarna kuning yaitu Turnera ulmifolia. Turnera subulata dapat tumbuh dan berbunga pada intensitas penyinaran tinggi dan dapat tumbuh pada ketinggian $10-250 \mathrm{~m}$ di atas permukaan laut.

Pada perkebunan kelapa sawit, Turnera subulata digunakan sebagai habitat serangga Sycanus dichotomus yang merupakan musuh alami ulat api. Sycanus dichotomus akan mencari nektar pada bunga pukul delapan yang sedang mekar. Menurut Hidayat dkk, 2018, tanaman Turnera subulata dan Turnera ulmifolia yang ditanam di sekitar kebun kelapa sawit mempunyai pengaruh yang berbeda dalam mengundang serangga phytophagous dan entomophagous. Turnera subulata dapat menarik serangga dua kali lebih banyak dibandingkan Turnera ulmifolia. Oleh karena itu semakin banyak bunga Turnera subulata yang mekar maka serangga tersebut akan semakin banyak sehingga dapat mengendalikan ulat api.

Pembungaan tanaman di antaranya dipengaruhi intensitas penyinaran dan panjang penyinaran atau fotoperiodisitas. Namun intensitas penyinaran mempunyai pengaruh yang lebih besar dan efeknya lebih konsisten dari pada fotoperiodisitas. Pengurangan intensitas penyinaran akan mengurangi inisiasi bunga .

Pembungaan tanaman selain dipengaruhi oleh intensitas penyinran juga dipengaruhi oleh suhu, kelembaban dan unsur hara sebagai faktor eksternal. Sedangkan faktor internal yang mempengaruhi pembungaan adalah fitohormon dan genetik. Pembentukan bunga sangat dipengaruhi unsur fosfor $(\mathrm{P})$. Fosfor juga berperan dalam pembentukan protein, membantu asimilasi, dan respirasi, pembentukan biji dan buah. 
Penelitian bertujuan untuk mengetahui respon pembungaan Turnera subulata pada beberapa perlakuan intensitas penyinaran matahari dan macam pupuk P. Penelitian ini diharapkan dapat dimanfaatkan sebagai salah satu upaya untuk pengendalian secara biologi hama ulat api yang banyak menyerang tanaman kelapa sawit. Hasil penelitian ini juga diharapkan dapat meningkatkan wawasan di bidang pengendalian secara bilogi yang ramah lingkungan.

\section{METODOLOGI}

Bahan tanam yang digunakan berupa stek Turnera subulata dengan panjang $20 \mathrm{~cm}$ yang ditanam dalam polibag. Penelitian dilakukan di lahan terbuka di Desa Maguwoharjo, Sleman, D.I Yogyakarta.

Penelitian menggunakan rancangan split plot yang terdiri dari dua faktor dengan 2 ulangan dan 2 plot perlakuan. Sebagai main plot adalah intensitas penyinaran yang terdiri dari ; 54,9 fc, 20,4 fc, 9,8 fc . Macam pupuk P sebagai sub plot yang terdiri dari ; Kontrol, TSP, SP36, Gandasil B.

Penelitian dilakukan menggunakan naungan paranet dengan beberapa tingkat penaungan, kemudian dilakukan pengukuran Intensitas Penyinaran menggunakan luxmeter yang hasilnya dikonversi ke foot candle (fc). Pengukuran intensitas penyinaran dilakukan selama penelitian pada saat kulminasi atas sedangkan pemupukan dengan beberapa macam pupuk diberikan dengan dosis $2 \mathrm{~g} /$ tanaman. Pemupukan dilakukan dua minggu sekali.

Parameter yang diamati meliputi tinggi tanaman, jumlah daun, umur berbunga, jumlah bunga, berat segar tanaman dan berat kering tanaman.

\section{HASIL DAN PEMBAHASAN}

Perlakuan intensitas penyinaran dan pupuk $P$ menunjukkan ada interaksi pada pertumbuhan vegetatif dan generatif tanaman Turnera subulata. Pada pertumbuhan generatif terlihat pada jumlah bunga (tabel 1). Intensitas penyinaran tinggi 54,9 fc (tanpa naungan) dan pemberian pupuk Gandasil B, ,jumlah bunga yang terbentuk paling banyak dibandingkan perlakuan lainnya. Pada intensitas penyinaran 54,9 fc dan pemberian pupuk TSP dan SP36 juga menunjukkan jumlah bunga yang muncul rata-rata per hari tinggi. Sedangkan pada intensitas yang lebih rendah (dengan naungan) yaitu 20,4 fc dan 9,8 fc, jumlah bunga yang muncul rata-rata per hari lebih sedikit walaupun diberikan tambahan pupuk P. Hal ini menunjukkan bahwa rendahnya intensitas penyinaran berpengaruh terhdap hasil fotosintesis 
sehingga bunga yang dihasilkan lebih sedikit. Hal ini sesuai pendapat Nurtjahyaningsih dkk, 2012, yang menyatakan bahwa proses pembungaan dipengaruhi oleh faktor internal seperti genetik, fitohormon dan faktor lingkungan seperti intensitas penyinaran dan unsur hara. Intensitas penyinaran akan berpengaruh terhadap laju fotosintesis sebagai sumber energi untuk proses pembungaan, sedangkan unsur hara dalam tanah menyediakan energi dan bahan pembentukan serta perkembangan bunga.

Intensitas penyinaran berpengaruh terhadap laju fotosintesis pada tanaman. Pada intensitas penyinaran yang lebih tinggi menunjukkan peningkatan jumlah daun sedangkan tinggi tanaman memberikan pengaruh yang sama (tabel 2). Hal ini sesuai dengan pendapat Widiastuti, et al, 2004, yang menyatakan interaksi antara intensitas penyinaran $75 \%$ dan kadar Dominosida 250 ppm menunjukkan hasil tertinggi secara nyata pada berat segar tajuk, nisbah tajuk-akar, diameter tajuk, jumlah bunga per tanaman, volume tanaman dan umur pajang tanaman Krisan dalam pot.

Tabel 1. Interaksi IP dan macam pupuk $P$ terhadap jumlah bunga per hari tanaman Turnera subulata

\begin{tabular}{lllcl}
\hline Intensitas penyinaran & \multicolumn{4}{c}{ Macam pupuk P } \\
& Kontrol & TSP & SP36 & Gandasil B \\
\hline $54,9 \mathrm{fc}$ & $2,42 \mathrm{e}$ & $15,74 \mathrm{~b}$ & $15,22 \mathrm{~b}$ & $28,05 \mathrm{a}$ \\
$20,4 \mathrm{fc}$ & $2,99 \mathrm{de}$ & $6,49 \mathrm{~cd}$ & $2,54 \mathrm{de}$ & $10,43 \mathrm{c}$ \\
$9,8 \mathrm{fc}$ & $0,27 \mathrm{e}$ & $2,28 \mathrm{e}$ & $1,74 \mathrm{e}$ & $2,21 \mathrm{e}$ \\
\hline
\end{tabular}

Keterangan : angka rerata yang diikuti notasi yang sama pada kolom dan baris

menunjukkan tidak ada beda nyata berdasatkan uji DMRT 5\%

Tabel 2. Pengaruh intensitas penyinaran pada pertumbuhan vegetatif Turnera subulata

\begin{tabular}{lccc}
\hline Parameter & \multicolumn{3}{c}{ Intensitas Penyinaran } \\
& $54,9 \mathrm{fc}$ & $20,4 \mathrm{fc}$ & $9.8 \mathrm{fc}$ \\
\hline Tinggi tanaman $(\mathrm{cm})$ & $50,05 \mathrm{a}$ & $66,11 \mathrm{a}$ & $48,53 \mathrm{a}$ \\
Jumlah daun & $1105,19 \mathrm{a}$ & $562,94 \mathrm{~b}$ & $239,38 \mathrm{~b}$ \\
Berat segar akar(g) & $16,18 \mathrm{a}$ & $9,90 \mathrm{a}$ & $3,74 \mathrm{a}$ \\
Berat kering akar(g) & $5,91 \mathrm{a}$ & $3,02 \mathrm{a}$ & $1,60 \mathrm{a}$ \\
\hline
\end{tabular}

Keterangan : angka rerata yang diikuti notasi yang sama pada kolom menunjukkan tidak ada beda nyata berdasatkan uji DMRT 5\% 
Intensitas penyinaran dan pemberian pupuk $\mathrm{P}$ dapat mempercepat pembungaan tanaman Turnera subulata. Pada intensitas penyinaran 54,9 fc dan pemberian pupuk Gandasil B, tanaman Turnera subulata berbunga lebih cepat dari pada perlakuan yang lainnya(tabel 3). Pada perlakuan intensitas penyinaran yang rendah $(9,8 \mathrm{fc})$ umur mulai berbunga semakin lama. Penambahan pupuk $P$ dapat mempercepat pembungaan tanaman Turnera subulata walaupun pada kondisi intensitas penyinaran lebih rendah (ternaungi).Sutoyo 2011 mengatakan bahwa fotoperiodisitas berpengaruh pada jumlah cadangan makanan dan menentukan waktu pembungaan pada banyak tanaman.

Tabel 3. Interaksi IP dan macam pupuk $\mathrm{P}$ terhadap umur (hari) berbunga Turnera subulata

\begin{tabular}{lcccc}
\hline Intensitas penyinaran & \multicolumn{4}{c}{ Macam pupuk P } \\
& Kontrol & TSP & SP36 & Gandasil B \\
\hline $54,9 \mathrm{fc}$ & $64,25 \mathrm{fg}$ & $51 \mathrm{bc}$ & $48,25 \mathrm{~b}$ & $45,25 \mathrm{a}$ \\
$20,4 \mathrm{fc}$ & $58,75 \mathrm{ef}$ & $52,25 \mathrm{bcd}$ & $54,01 \mathrm{bcde}$ & $53,25 \mathrm{bcde}$ \\
$9,8 \mathrm{fc}$ & $73,50 \mathrm{~h}$ & $66 \mathrm{~g}$ & $55,50 \mathrm{cde}$ & $57,78 \mathrm{de}$ \\
\hline
\end{tabular}

Keterangan: angka rerata yang diikuti notasi yang sama pada kolom dan baris menunjukkan tidak ada beda nyata berdasatkan uji DMRT 5\%

Tabel 4. Interaksi IP dan macam pupuk P terhadap berat kering $(\mathrm{g})$ tajuk Turnera subulata

\begin{tabular}{ccccc}
\hline Intensitas penyinaran & \multicolumn{4}{c}{ Macam pupuk P } \\
& Kontrol & TSP & SP36 & Gandasil B \\
\hline $54,9 \mathrm{fc}$ & $11,77 \mathrm{f}$ & $25,69 \mathrm{~b}$ & $23,01 \mathrm{c}$ & $32,82 \mathrm{a}$ \\
$20,4 \mathrm{fc}$ & $14,89 \mathrm{e}$ & $18,41 \mathrm{~d}$ & $16,59 \mathrm{de}$ & $25,98 \mathrm{~b}$ \\
$9,8 \mathrm{fc}$ & $5,91 \mathrm{~g}$ & $12,41 \mathrm{~g}$ & $6,14 \mathrm{~g}$ & $11,13 \mathrm{f}$ \\
\hline
\end{tabular}

Keterangan: angka rerata yang diikuti notasi yang sama pada kolom dan baris menunjukkan tidak ada beda nyata berdasatkan uji DMRT 5\%.

Peningkatan jumlah bunga yang terbentuk didukung oleh pertumbuhan vegetatif yang baik. Pada perlakuan intensitas penyinaran 54,9 fc dan pemberian pupuk Gandasil B menunjukkan pertumbuhan tajuk dan tanaman yang lebih tinggi dibandingkan kombinasi perlakuan lainnya (tabel 4 dan 5) 
Tabel 5. Interaksi IP dan macam pupuk $\mathrm{P}$ terhadap berat kering $(\mathrm{g})$ tanaman Turnera subulata

\begin{tabular}{ccccc}
\hline Intensitas penyinaran & \multicolumn{4}{c}{ Macam pupuk P } \\
& Kontrol & TSP & SP36 & Gandasil B \\
\hline $54,9 \mathrm{fc}$ & $14,26 \mathrm{fg}$ & $31,77 \mathrm{~b}$ & $28,65 \mathrm{c}$ & $42,23 \mathrm{a}$ \\
$20,4 \mathrm{fc}$ & $17,04 \mathrm{ef}$ & $21,29 \mathrm{~d}$ & $18,95 \mathrm{de}$ & $30,64 \mathrm{bc}$ \\
$9,8 \mathrm{fc}$ & $6,74 \mathrm{~h}$ & $14,22 \mathrm{fg}$ & $7,94 \mathrm{~h}$ & $13,09 \mathrm{~g}$
\end{tabular}

Keterangan: angka rerata yang diikuti notasi yang sama pada kolom dan baris menunjukkan tidak ada beda nyata berdasatkan uji DMRT 5\%

\section{KESIMPULAN}

1. Respon Turnera subulata pada jumlah bunga lebih banyak pada kondisi intensitas penyinaran tinggi (54,9 fc) dan pemberian pupuk Gandasil B.

2. Umur mulai berbunga tanaman Turnera subulata paling cepat terjadi pada perlakuan intensitas penyinaran tinggi dan pemberian pupuk Gandasil B.

3. Pertumbuhan vegetatif Turnera subulata mendukung respon pembungaan Turnera subulata

\section{DAFTAR PUSTAKA}

Dongoran, A.P., Agus Susanto, A. Smanjuntak, 2007. Potensi Patogenesis Jamur Paecilomyces fumosoroseus dan Beauveria bassiana Terhadap Hama Ulat Api Setothosea asigna, Warta PPKS 15(1): 1- 5

Hidayat, R.; Chandra I.; Arum S. 2018. Diversity of Phytophagous and Entomophagous Insect on Yellow Alder Flower (Turnera subulata E.SM and Turnera ulmifolia L) Around The Palm Oil (Elaeis guinensis J.) Plantation. Science and Technology Indonesia 3 (3), 130-133.

Lubis, Rustam Effendi, dan Agus Widanarko. 2011. Buku Pintar Kelapa Sawit. Jakarta: Agromedia Pustaka.

Nurtjahjaningsih 2021. Karakteristik Pembungaan dan Sistem Perkawinan Nyamplung (Calophyllum inophyphyllum) Pada Hutan Tanaman di Watusipit,Gunung Kidul. Pemuliaan Tanaman Hutan 6 (2), 65-80.

Pahan, I. 2008. Panduan Lengkap Kelapa Sawit, Manajemen Agribisnis dari Hulu hingga Hilir. Jakarta: Penebar Swadaya.

Rahutomo,S.,H.H.Siregar, dan E.S. Sutarta, 2007. Irigasi pada Perkebunan Kelapa Sawit: Sebuah Tinjauan, Warta PPKS 15 (1): 7 - 18. 
Sutoyo. 2011. Fotoperiode dan Pembungaan Tanaman. Buana Sains 11 (2), 137-144.

Widiastuti, Libria. Prof.Dr.Ir.Tohari,MSc.2004. Pengaruh Intensitas Cahaya dan Kadar Daminosida Terhadap Pertumbuhan dan Pembungaan Tanaman Krisan Dalam Pot. http://etd.repository.ugm.ac.id/2021/12/20. 